\title{
Arrhythmogenic right ventricular cardiomyopathy type 1 (ARVD1): confirmation of locus assignment and mutation screening of four candidate genes
}

\author{
Alessandra Rampazzo ${ }^{1}$, Giorgia Beffagna ${ }^{1}$, Andrea Nava ${ }^{2}$, Gianluca Occhi ${ }^{1}$, Barbara Bauce ${ }^{2}$, \\ Massimo Noiato ${ }^{1}$, Cristina Basso ${ }^{3}$, Gianfranco Frigo ${ }^{2}$, Gaetano Thiene ${ }^{3}$, Jeffrey Towbin ${ }^{4}$ \\ and Gian Antonio Danieli*,1
}

${ }^{1}$ Department of Biology, University of Padua, Padua, Italy; ${ }^{2}$ Department of Cardiology, University of Padua, Padua, Italy; ${ }^{3}$ Department of Pathology, University of Padua, Padua, Italy; ${ }^{4}$ Department of Pediatrics, Pediatric Cardiology, Baylor College of Medicine, Houston, Texas, USA

Arrhythmogenic right ventricular cardiomyopathy type 1 (ARVD1) is an autosomal dominant disorder characterised by progressive degeneration of right ventricular myocardium, arrhythmias and risk of sudden death. By linkage analysis, we previously mapped the involved gene to chromosome 14q24.3. In the present study we report on linkage analysis of one additional and unrelated family, which enabled to confirm previous locus assignment. Another family is reported, in which genetic and clinical data suggest linkage to the same locus. Direct sequencing of DNA from individuals belonging to established ARVD1 families failed to detect causative mutations in exonic sequences of four genes (POMT2, TGF $\beta 3$, KIAAA1036 and KIAA0759) expressed in the heart and which defects could possibly induce plasma membrane instability or apoptosis, key features of ARVD pathogenesis.

European Journal of Human Genetics (2003) 11, 69-76. doi:10.1038/sj.ejhg.5200914

Keywords: ARVD1; sudden cardiac death; arrhythmogenic cardiomyopathy; candidate gene

\section{Introduction}

Arrhythmogenic Right Ventricular Dysplasia (ARVD) is a cardiomyopathy characterised by progressive degeneration and fibrous-fatty replacement of right ventricular myocardium, ${ }^{1}$ by arrhythmias with a left branch block pattern ${ }^{2}$ and by increased risk of sudden death in juveniles. ${ }^{1,3}$ Several forms of dominant arrhythmogenic right ventricular cardiomyopathy/dysplasia (ARVD, OMIM 107970) were identified so far: ARVD1 (14q24.3), ${ }^{4}$ ARVD2 (1q42), ${ }^{5}$ ARVD3 (14q11-q12), ${ }^{6}$ ARVD4 (2q32), ${ }^{7}$ ARVD5 (3p23), ${ }^{8}$ ARVD6 (10p12-p14) ${ }^{9}$ and ARVD7 (10q22). ${ }^{10}$ Mutations in the gene encoding the cardiac ryanodine receptor were recently detected in patients affected with ARVD2. ${ }^{11}$ Attempts to

\footnotetext{
*Correspondence: GA Danieli, Department of Biology, University of Padova, Via U. Bassi 58/B, I-35131 Padova. Tel: +390498276214; fax: +390498276209; E-mail: danieli@bio.unipd.it.

Received 7 March 2002; revised 10 July 2002; accepted 10 October 2002
}

identify genes involved in other dominant ARVDs were so far unsuccessful. ${ }^{12-15}$

Here we report on linkage analysis of a novel family affected with ARVD, which enabled to confirm previous chromosomal localisation of ARVD1. We report as well on another novel family probably belonging to the same clinical-genetic entity and on mutation screening of four candidate genes.

\section{Materials and methods}

Families

Two independent ARVD families were investigated at the Department of Cardiology of the University of Padua (Italy). Informed consent was obtained from all the family members participating in the study. Diagnostic criteria were according to McKenna et al. ${ }^{16}$ Peripheral blood samples were collected from ARVD family members in EDTA-coated tubes and genomic DNA was prepared from nucleated blood cells, according to the salting out method. In total 35 individuals were studied, including 15 affected subjects. 
Haplotype and linkage analysis

PCR primers sequences for the different genetic markers were obtained from The Genome Database (http:// gdbwww.gdb.org/gdb/gdbtop.html). The following markers of ARVD1 locus were used for haplotyping and linkage studies: D14S994, D14S1036, D14S61, D14S42, D14S279, D14S983, D14S59, D14S254, D14S1020, D14S74 and D14S127. Two additional polymorphic markers (GenBank/ EMBL Data Libraries accession No. AJ422208 and AJ422209, respectively), identified between D14S74 and D14S127, were used to further refine the critical region.

The following markers were used to assess linkage to other known ARVD loci: D1S2800, D1S2850, D1S2670, D1S2785, D1S304, D1S2842 for ARVD2 critical region; D14S252, D14S257, D14S70 for ARVD3 critical region; D2S152, D2S364, D2S118, D2S117, D2S72, D2S2358 for ARVD4 critical region; D3S3610, D3S2403, D3S3613, D3S2338, D3S3659, D3S1293 for ARVD5 critical region; D10S547, D10S570, D10S191, D10S1653 for ARVD6 critical region; D10S605, D10S201, D10S1777, D10S1786, D10S1696, D10S1686, D10S1744, D10S215 for ARVD7 critical region.

The analysis of the microsatellite markers were performed as described elsewhere. ${ }^{4}$ Two-point lod scores between ARVD and the marker loci were calculated by the MLINK programme of the LINKAGE package (vs 5.02). The disease was assumed as autosomal dominant with both 70 and $95 \%$ penetrance and with a frequency of 0.01 in the population. Equal allele frequencies for the markers tested were assumed. FASTMAP programme was used to perform multipoint linkage analysis.

\section{Bioinformatic analysis of the ARVD1 critical region}

The sequence of the entire critical region was obtained from the working draft of the human genome sequence (http://genome.ucsc.edu). Annotated known genes, expressed-sequence tags (ESTs) and cDNAs were searched for in this genomic sequence. Their expression in the human heart tissue was established according to Unigene (http://www.ncbi.nlm.nih.gov/UniGene/Hs.Home.html) and STACK (http://juju.egenetics.com/stackpack/webblast.html) databases.

\section{Reconstruction of the genomic structure of candidate genes}

The genomic structures of POMT2, TGF $\beta 3$, KIAA1036 and KIAA0759 were reconstructed by direct comparison of their full length cDNAs with the sequence of human chromosome 14 genomic clones, retrieved from the GenBank/htgs database (http://www.ncbi.nlm.nih.gov) by BLASTN search.

\section{Prediction of additional gene structure/protein elements of KIAA1036 and KIAA0759}

DNA sequence and the translated amino acid sequences were compared with the nonredundant nucleotide and protein sequence databases using BLASTN and BLASTP, respectively. ${ }^{17}$ Protein motif and profile searches were performed with ScanProsite (http://www.expasy.ch/tools/ scnpsite.html) and ProfileScan (http://www.isrec.isb-sib.ch). Transmembrane domains were predicted using TM-pred (http://www.ch.embnet.org). The prediction of protein sorting signals and of protein localization sites in cells was carried out with PSORT (http://psort.nibb.ac.jp).

\section{RT - PCR}

For RT-PCR analysis, PCR amplification was performed with cDNA (from human adult myocardium) as template, by using the following primers. Primer KIAA1036F, 5'-TCGGACCCTAATTCACCTTA-3'; KIAA1036R, 5'-TCCCTGTGTGATTGTACTGC-3'; KIAA0759F, 5'-ATTGGAACTATCGCTCCGTG-3'; KIAA0759R, 5'- TCTGGTAAAGCTGATGGGAG-3'; TGF $\beta 3$ F, 5'-GTGGAAGCCATTAGGGGACA-3', TGF $\beta 3 R, \quad 5$ ATTCCGCTTAGAGCTGGGGT-3'; POMT2F, 5'-ATCAGGGCCTACGCTTCTCA-3', POMT2R, 5'- GTCCCACAGAATGCCTGTCA-3'

PCR experiments were carried out in a reaction buffer $(12.5 \mu \mathrm{l})$ containing $2 \mu \mathrm{l}$ of cDNA derived from $5 \mu \mathrm{g}$ total RNA, 5 pMoli oligonucleotide primers, $1 \mu \mathrm{l}$ DMSO and $0.2 \mathrm{U}$ of Taq DNA polymerase (ExperTeam). An aliquot of the amplified products was subjected to $2 \%$ agarose gel electrophoresis and stained by ethidium bromide. Amplified products were visualised by UV light. RT-PCR products were then subjected to direct DNA sequencing analysis.

\section{Mutation screening}

PCR primers flanking the exons of each candidate gene for amplification from genomic DNA for mutation screening were designed by PRIMER3 (http://www-genome.wi.mit.e$\mathrm{du}$ ). The sequences of primers are listed in Table 4. Mutation screening was performed by direct sequencing of both strands. Each exon was amplified from patient genomic DNA, purified (PCR Product Pre-Sequencing kit; USB) and sequenced using the BIG DYE dideoxy-terminator chemistry (Perkin Elmer) on an ABI 377 DNA sequencer (PE Applied Biosystems). Chromas 1.5 software (Technelysium) and LASERGENE package computer programmes (DNASTAR) were used to edit, assemble and translate sequences.

\section{Results}

\section{Clinical data}

A family (Fam. 112) from Northern Italy, showing recurrence of ARVD cases and unrelated to those described in the original article ${ }^{4}$ was investigated. Clinical features, summarized in Table 1A, fitted a 'classical' form of ARVD.

\section{Linkage analysis}

Pedigree of family 112 is shown in Figure1A, along with haplotypes corresponding to part of chromosomal region 14q24.3-q31.1. Two point lod scores for 11 microsatellite markers are shown in Table 2 . Maximum lod scores at $\theta=0$ 
Table 1 ARVD Patient belonging to family $112(1 \mathrm{~A})$ and family 119 (1B) considered in the present study A

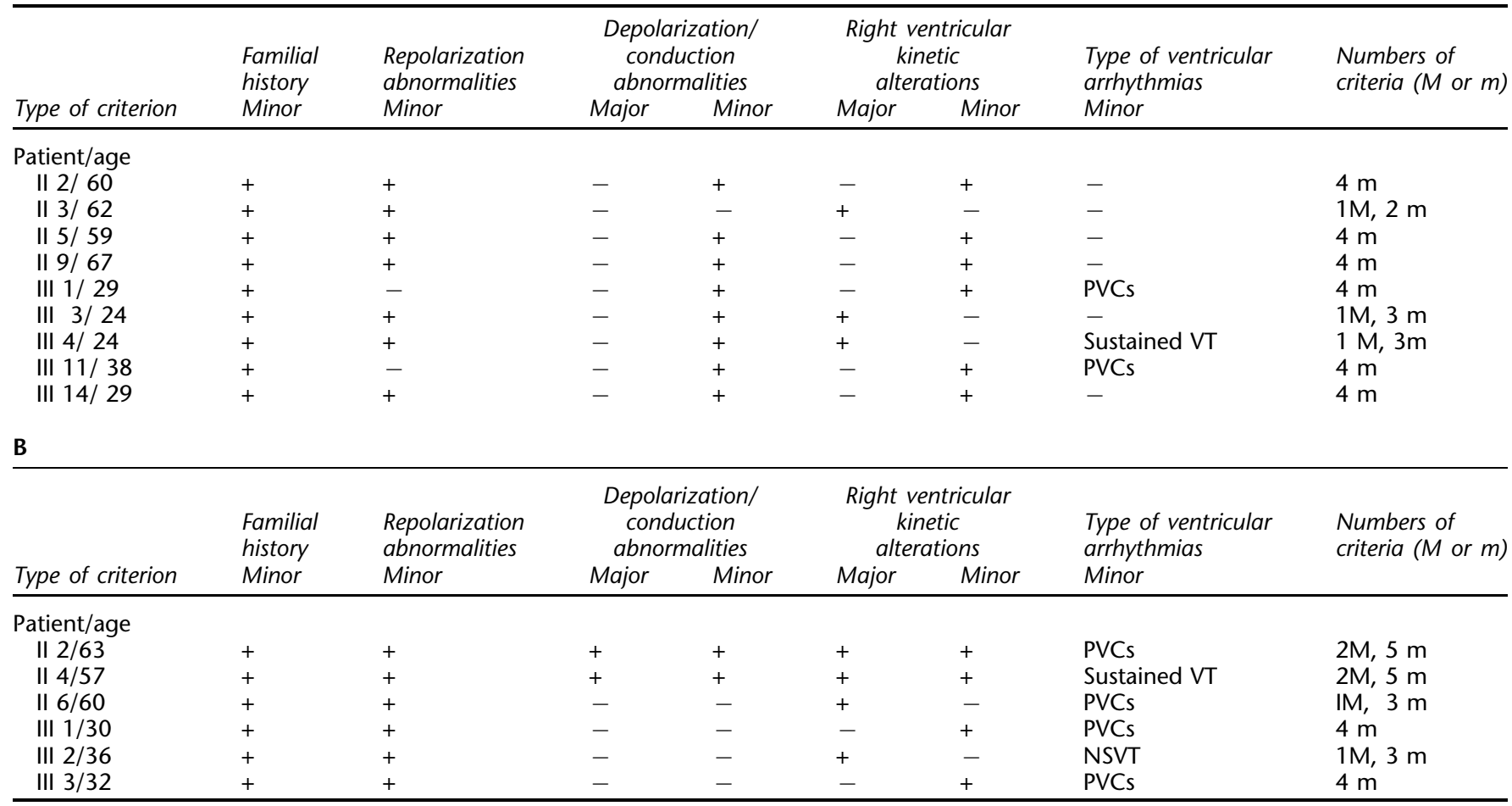

NOTE: M: major criterion, m: minor criterion; PVC: premature ventricular complex; NSVT: non sustained VT; VT: ventricular tachycardia

(assuming 95\% of penetrance) were obtained with marker D14S254 ( $Z=4.41)$, and marker D14S983 ( $Z=4.06)$. The 'affected only' lod score resulted close to the level of significance (2.71 for markers D14S983 and D14S59, at $\theta=0$ ).

Multipoint linkage analysis (peak lod score $Z=5.20$ ) suggested that the most likely location of ARVD1 is between D14S279 and D14S283 (data not shown). Unfortunately, no recombinants were detected in the family.

An additional family (Family 119, Figure 1B), from South Germany, was investigated because patients showed clinical features consistent with the hypothesis of ARVD1 (Table 1B).

Preliminary haplotype investigation, by means of a panel of markers for each of the ARVD loci identified so far, showed that segregation was consistent only with the hypothesis of association of the disease to ARVD1 locus. Haplotype sharing analysis was performed on affected members of Family 119 and on their relatives, by using the same microsatellite markers tested in Family 112. The at-risk haplotype of Family 119 resulted differently from that detected in Family 112.

In family 119, affected individuals II, 6 and III, 2 showed recombinations between markers D14S74 and D14S127 and between D14S1036 and D14S61, respectively (Figure 1B). Small size of family 119 failed to produce significant lod scores by linkage analysis. However, it is worth noticing that a lod score of 1.51 was obtained for marker D14S59.

\section{Mutation screening of candidate genes}

Mutation screening on coding sequences of four candidate genes (POMT2, TGF $\beta 3$, KIAA0759 and KIAA1036) included in the ARVD1 critical region was attempted. Mutations in three of the selected genes could possibly induce plasma membrane instability or apoptosis, which are presently believed as primary steps in ARVD pathogenesis ${ }^{4,16-18}$; the fourth gene was considered because it is expressed in heart, although its function is still unknown.

After genomic structure of these genes was determined by gapped BLAST comparison of cDNA sequences with genomic DNA sequences available in GenBank, PCR primers were designed. RT-PCR on total RNA extracted from normal human heart demonstrated that all these genes are expressed in cardiac tissue (data not shown). Data about the four candidate genes are summarized in Table 3.

PCR primers (Table 4), designed to flank each exon, were used to screen genomic DNA from two ARVD1 patients, belonging to the two ARVD1 families identified so far in our laboratory (Fam 100 of the previous study and Fam 112 , this study) and from one healthy control subject. POMT2, TGF $\beta 3$, KIAA1036 and KIAA0759 coding sequences 

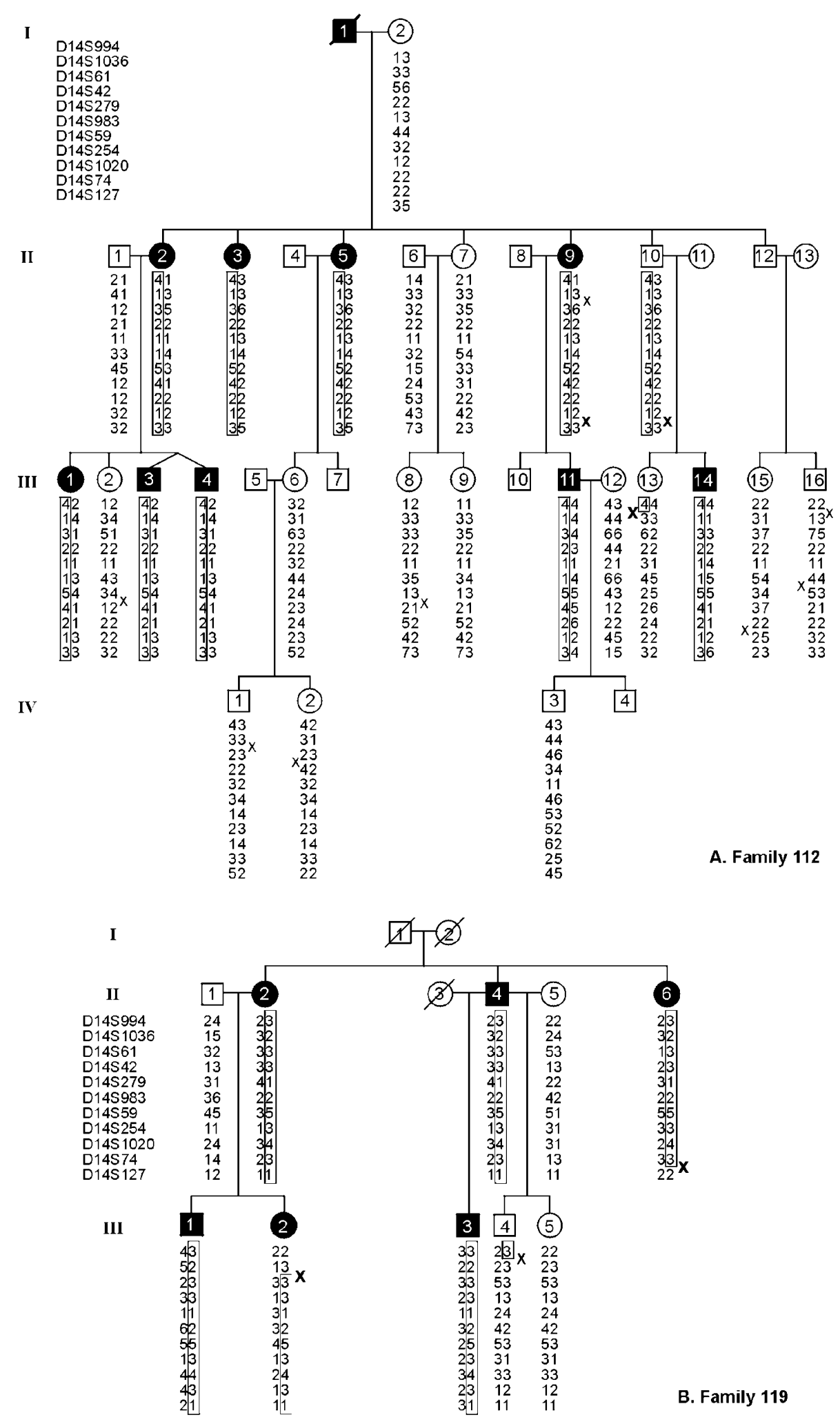

Figure 1 Pedigree of family 112 and 119. Affected subjects fulfilled the classic clinical criteria for ARVD. Haplotypes are indicated where DNA was available. Boxed haplotypes represent the at-risk chromosome. In family 119, the affected individuals II, 6 and III, 2 show key recombinations between markers D14S1036 and D14S61 and between D1GS74 and D14S127. Thus, the most likely interval for a localisation of the disease gene is between the genetic markers D14S1036 and D14S127. 
Table 2 Two-point lod scores for different values of recombination fraction, for 11 markers of the chromosome 14 in the family 112 with recurrence of ARVD/C, reported in Figure 1A. Lod scores were calculated for two different values of penetrance (a: 70\%; b: 95\%)

\begin{tabular}{|c|c|c|c|c|c|c|c|c|c|c|}
\hline \multicolumn{11}{|c|}{ Recombination fraction } \\
\hline Marker & & 0.00 & 0.01 & 0.05 & 0.10 & 0.20 & 0.30 & 0.40 & $\theta \max$ & $Z \max$ \\
\hline \multirow[t]{2}{*}{ D14S994 } & $\mathrm{a}$ & 2.86 & 2.82 & 2.65 & 2.43 & 1.90 & 1.27 & 0.54 & 0.00 & 2.86 \\
\hline & $b$ & 1.81 & 1.90 & 2.08 & 2.10 & 1.82 & 1.31 & 0.63 & 0.10 & 2.10 \\
\hline \multirow[t]{2}{*}{ D14S1036 } & $a$ & 2.88 & 2.84 & 2.66 & 2.41 & 1.87 & 1.23 & 0.53 & 0.00 & 2.88 \\
\hline & $b$ & 2.52 & 2.54 & 2.52 & 2.39 & 1.96 & 1.36 & 0.64 & 0.01 & 2.54 \\
\hline \multirow[t]{2}{*}{ D14S61 } & $\mathrm{a}$ & 1.99 & 1.97 & 1.87 & 1.72 & 1.35 & 0.92 & 0.44 & 0.00 & 1.99 \\
\hline & $\mathrm{b}$ & 2.27 & 2.26 & 2.17 & 2.02 & 1.63 & 1.15 & 0.61 & 0.00 & 2.27 \\
\hline \multirow[t]{2}{*}{ D14S42 } & $\mathrm{a}$ & 0.20 & 0.20 & 0.19 & 0.18 & 0.14 & 0.10 & 0.05 & 0.00 & 0.20 \\
\hline & $b$ & 0.26 & 0.26 & 0.25 & 0.24 & 0.20 & 0.14 & 0.07 & 0.00 & 0.26 \\
\hline \multirow[t]{2}{*}{ D14S279 } & $\mathrm{a}$ & 0.40 & 0.39 & 0.36 & 0.33 & 0.24 & 0.16 & 0.08 & 0.00 & 0.40 \\
\hline & $b$ & 0.50 & 0.50 & 0.47 & 0.43 & 0.35 & 0.24 & 0.13 & 0.00 & 0.50 \\
\hline \multirow[t]{2}{*}{ D14S983 } & $a$ & 3.57 & 3.51 & 3.25 & 2.92 & 2.21 & 1.44 & 0.61 & 0.00 & 3.57 \\
\hline & $b$ & 4.06 & 4.00 & 3.72 & 3.35 & 2.58 & 1.72 & 0.79 & 0.00 & 4.06 \\
\hline \multirow[t]{2}{*}{ D14S59 } & $a$ & 3.56 & 3.50 & 3.26 & 2.94 & 2.26 & 1.50 & 0.65 & 0.00 & 3.56 \\
\hline & $b$ & 3.93 & 3.87 & 3.61 & 3.28 & 2.55 & 1.73 & 0.82 & 0.00 & 3.93 \\
\hline \multirow[t]{2}{*}{ D14S254 } & $a$ & 3.90 & 3.84 & 3.58 & 3.23 & 2.49 & 1.65 & 0.73 & 0.00 & 3.90 \\
\hline & $b$ & 4.41 & 4.34 & 4.06 & 3.69 & 2.88 & 1.97 & 0.94 & 0.00 & 4.41 \\
\hline \multirow[t]{2}{*}{ D14S1020 } & $a$ & 0.28 & 0.27 & 0.26 & 0.24 & 0.19 & 0.12 & 0.06 & 0.00 & 0.28 \\
\hline & $b$ & 0.26 & 0.27 & 0.26 & 0.25 & 0.21 & 0.15 & 0.08 & 0.01 & 0.27 \\
\hline \multirow[t]{2}{*}{ D14S74 } & $a$ & 3.35 & 3.29 & 3.05 & 2.74 & 2.07 & 1.34 & 0.57 & 0.00 & 3.35 \\
\hline & $b$ & 3.76 & 3.70 & 3.44 & 3.10 & 2.37 & 1.58 & 0.72 & 0.00 & 3.76 \\
\hline \multirow[t]{2}{*}{ D14S127 } & $a$ & 1.84 & 1.81 & 1.67 & 1.49 & 1.11 & 0.69 & 0.26 & 0.00 & 1.84 \\
\hline & $b$ & 2.14 & 2.10 & 1.95 & 1.76 & 1.34 & 0.87 & 0.36 & 0.00 & 2.14 \\
\hline
\end{tabular}

Table 3 General information of candidate ARVD1 genes submitted to screening for mutations

\begin{tabular}{|c|c|c|c|c|}
\hline $\begin{array}{l}\text { Gene } \\
\text { (Base } \\
\text { Position) }\end{array}$ & $\begin{array}{l}\text { Flanking } \\
\text { markers }\end{array}$ & $\begin{array}{l}\text { Genomic } \\
\text { Size }(K b)\end{array}$ & $\begin{array}{l}\text { No. of } \\
\text { exons }\end{array}$ & Domains and activity \\
\hline $\begin{array}{l}\text { POMT2 } \\
\text { (75785446- } \\
75829352)\end{array}$ & $\begin{array}{l}\text { D14S983 } \\
\text { D14S59 }\end{array}$ & 43.9 & 21 & $\begin{array}{l}\text { POMT2 encodes an O-mannosyltransferase, catalyzing the first step in O-glycosylation. Protein } \\
\text { O-mannosylation plays an essential role in a number of physiologically important processes, } \\
\text { among which is maintenance of cell wall integrity. Four domains present as a triplet in } \\
\text { O-mannosyltransferases (MIR domain) are found also in the N-terminals of Ryanodine receptors } \\
\text { (RyRs) and inositol } 1,4,5 \text {-triphosphate receptors (IP3Rs). O-mannosyltransferases transfer mannose } \\
\text { from DOL-P-mannose to ser or thr residues on proteins [19]. The presence of an uncommon } \\
\text { O-linked mannosyl glycan was found in bovine peripheral nerve and rabbit skeletal } \\
\text { muscle } \alpha \text {-dystroglycans [20,21], an extracellular peripheral membrane glycoprotein binding } \\
\text { to a transmembrane glycoprotein, } \beta \text {-dystroglycan. The } \alpha \text {-dystroglycan- } \beta \text {-dystroglycan complex } \\
\text { acts as a transmembrane linker between the extracellular matrix and intracellular cytoskeleton [22]. }\end{array}$ \\
\hline $\begin{array}{l}\text { TGF } \beta 3 \\
(74466566- \\
74489613)\end{array}$ & $\begin{array}{l}\text { D14S61 } \\
\text { D14S270 }\end{array}$ & 23 & 7 & $\begin{array}{l}\text { TGF } \beta \text { is a multifunctional cytokine. The protein is an homodimer, disulfide-linked. TGF } \beta \text { is known } \\
\text { to modulate several tissue development and repair processes, including cell differentiation, cell } \\
\text { cycle progression, cellular migration, cell adhesion, and extracellular matrix production. The } \\
\text { different effects of TGF } \beta \text { are mediated by the TGF } \beta \text { receptors and cell surface-binding proteins [23]. } \\
\text { TGF } \beta \text { is a potent growth inhibitor and inducer of apoptosis [24]. }\end{array}$ \\
\hline $\begin{array}{l}\text { KIAA1036 } \\
\text { (75270912- } \\
75291491)\end{array}$ & $\begin{array}{l}\text { D14S42 } \\
\text { D14S279 }\end{array}$ & 20.6 & 7 & $\begin{array}{l}\text { No significant sequence homology was identified using the BLAST server. No obvious structural } \\
\text { features or motifs were found. Several potential phosphorylation and N-glycosylation sites are } \\
\text { present. Sequence analysis with the TM-pred program showed no significant transmembrane } \\
\text { helices. Function of this gene is unknown. }\end{array}$ \\
\hline
\end{tabular}


Table 4 Oligonucleotide primers used for PCR amplification and DNA sequencing of the exons of POMT2, TGF $\beta 3$, KIAA1036 and KIAA0759 genes

\begin{tabular}{|c|c|c|c|c|c|}
\hline Gene & $\begin{array}{l}\text { Exon } \\
\text { No. }\end{array}$ & $\begin{array}{l}\text { Product } \\
(p b)\end{array}$ & Forward primer $\left(5^{\prime} \rightarrow 3^{\prime}\right)$ & Reverse primer $\left(5^{\prime} \rightarrow 3^{\prime}\right)$ & $\begin{array}{l}\text { Annealing } \\
\text { Temp }\left({ }^{\circ} \mathrm{C}\right)\end{array}$ \\
\hline \multirow[t]{14}{*}{ POMT2 } & 1 & 296 & GTACCCTCGGGCCAATCAG & GAGAGTCCGAGCTGCGTC & 65 \\
\hline & & 314 & ССАТСАСТСАССАGATGTGC & GCTGGTCAGACAAAGTGTGC & 60 \\
\hline & 3 & 297 & САССАСССАAАGTСССТTТА & GGAGGGAAGTTCAGAGGACA & 60 \\
\hline & 4 & 236 & AGCTACATTCACGGAGTGGC & TGAGTCCAGTAGGTCGCTGA & 60 \\
\hline & 5 & 212 & AATTTTGGAGTTGCCACAGC & GСССТTСТСТTАССТСGСТT & 60 \\
\hline & 8 & 210 & TTTCСААТTCAАСТСССАGG & CCTGGGAAATCACACTTTCA & 60 \\
\hline & 9 & 223 & GTGAACTGTCATGGCGAACA & GGACAGCCTCTGGCACTGT & 60 \\
\hline & 10 & 197 & СTTAAGGAGGGCTCAGAGGG & GCCAGCGTGTCTGATAGTGA & 65 \\
\hline & 11 & 253 & CCATTGACCAGAGCCTCATC & TGTTTACCAGTAGGCCCTTGA & 60 \\
\hline & 12 & 226 & AGCCAAGGCCCATAACTTTT & ТССТGАСАGTTGАСТСТGАACA & 60 \\
\hline & 13 & 277 & AAGGAAAATCAGGACCCTCG & СGTTTTCTCTAAAGTCСССТСA & 60 \\
\hline & 14 & 190 & TAAATGCTTCССТCCAGAGC & TCTGGTGGATTTCACGTCTTC & 60 \\
\hline & 20 & 218 & CTGAGCCCACACTGGGAG & CTGTAGCCCAGAAGTCACCC & 65 \\
\hline & 21 & 246 & GTCCAGTACTGCTTCCCAGC & AATGGAATTCAAAGCСССТC & 65 \\
\hline \multirow[t]{9}{*}{ TGF $\beta 3$} & 1 & 301 & CTCCCAGCTCCAGTTCAGAC & AGAAGAGGGTGGAAGCCATT & 65 \\
\hline & & 307 & GTAAAGGGCCAGGACCTGAT & TGGTTTTCCTCССТCСТTCT & 65 \\
\hline & 2 & 281 & TATGGCAAAGGAACCAGCTT & GCACACTGTTCCTGCATGTC & 65 \\
\hline & 3 & 326 & ТGTССТСТTСССТССАТTTСА & CATGGCATTCAGGAACCACT & 60 \\
\hline & 4 & 233 & CTTTTGGGGCAAAGCAGATT & CCCTATAGGAGCAGAGGCCC & 68 \\
\hline & 5 & 319 & АСССТСТGTTGAGTGTGGCT & GGGCTCTGCTCTCTTCAGAC & 60 \\
\hline & 6 & 307 & AACAAGTGGTCTGGTCGGTC & CATGAAAGGACTCCAAGGGA & 62 \\
\hline & 7 & 285 & TGTTGCTTGTGTGTTTCCC & СTGAGACTTGGCСТTCCAAC & 62 \\
\hline & & 325 & СССТТССТТСТСССТТТАG & GAGAGAGAACCACCACTGCC & 58 \\
\hline \multirow[t]{3}{*}{ KIAA0759 } & 1 & 234 & GGGCACGGTAGTCGTGAG & GAGCTGAGGGAGGACCTG & 65 \\
\hline & 2 & 423 & СТСТTTAGCAATGGСТСТTGC & GAGAATGCTCGCTTCAGAGGA & 62 \\
\hline & & 393 & AAGGCTCATCCAGGTTCTCT & TGGGCTTATGTTTTAGCTGG & 62 \\
\hline \multirow{7}{*}{ KIAA1036 } & 1 & 404 & ССTCTTGTGAGCCAGTTGTT & ССTAGACTGTGCTATCACCC & 58 \\
\hline & 2 & 168 & ACTGGAAGCTCCAAGGTGA & GACCCTTGACCAGAGAGGAT & 58 \\
\hline & 3 & 166 & AGAGGGTCAACCTCCTTCAG & ТTTCAAGAAGCTCCAAGCC & 55 \\
\hline & 4 & 194 & ТССТТСТСАСАТТССССТG & AGCTGAGGCCCAGAGAAG & 58 \\
\hline & 5 & 497 & СGTGCTTCTCСTGGCTCT & СААТССТСАСАТСGССТСТ & 58 \\
\hline & 6 & 240 & CTGGAAGGAGAGGTTGGG & CGATGAGAGAGGAAAGGAAAAA & 58 \\
\hline & 7 & 269 & ССАТСТСССТААСАGАССАС & GGCTGAGCTGGAACACACT & 58 \\
\hline
\end{tabular}

were screened for mutations by sequencing exons and intron-exon boundaries. Although single-nucleotide substitutions were detected in these genes, no ARVD1-specific sequence alterations were identified (Table 5).

\section{Discussion}

In one novel family fulfilling diagnostic criteria for ARVD and unrelated to those previously described, significant linkage to ARVD1 was detected. This is the first evidence confirming the early locus assignment. It is interesting to notice that no additional linkage data were reported so far for any of the other ARVD forms, if we excluded ARVD $2^{27}$, which involved gene was recently identified in our laboratory. ${ }^{11}$

An additional family was investigated in which haplotype analysis excluded linkage to any of known ARVD 
Table 5 Single-nucleotide polymorphisms in the ARVD1 candidates genes

\begin{tabular}{lllll}
\hline Transcript & Location & Position & Polymorphism & Coding change \\
\hline KIAA0759 & & & No polymorphism & \\
KIAA1036 & Exon2 & 729 & TA(T/C)ATCAG & None (Tyrosine) \\
KIAA1036 & Intron & $/$ & CCA(C/T)AGGC & None (Arginine) \\
POMT2 & Exon 13 & 1587 & AAA(A/G)GAC & 5'UTR \\
TGF $\beta 3$ & Exon 1 & 234 & GCC(G/A)TCCC & \\
\hline
\end{tabular}

loci, except ARVD1. However, the small size of the family impeded to obtain significantly positive lod scores by linkage analysis. The at-risk haplotype in this family appeared different from that detected in Family 112. This is not surprising, due to the different geographical origin of the two families. If we would accept that the disease in family 119 is linked to ARVD1 locus, recombinations detected in this family (between disease and D14S1036 and D14S127) would narrow the ARVD1 critical region to approximately $7.9 \mathrm{Mb}$.

The critical interval for ARVD1 is very large. Nevertheless, we attempted to screen for ARVD1-causing mutations coding sequences of four genes (POMT2, TGF $\beta 3$, KIAA1036 and KIAA0759), after having proved that they are expressed in the heart. These genes were selected on the basis of the possible role of their mutations in ARVD pathogenesis, as suggested by identification of pathogenic mutations in the gene encoding cardiac Ryanodine receptor (RYR2/ARVD2) and in the Plakoglobin gene (JUP, involved in Naxos disease, an autosomal recessive form of ARVD). Actually, mutations in three selected genes might produce plasma membrane instability or apoptosis, which are presently believed to be primary steps in ARVD pathogenesis ${ }^{4,16-}$ 18 , while fourth gene was considered because it is placed in the region corresponding to the maximum location score, it is expressed in the heart tissue and its function is still unknown.

Mutation screening of the coding regions and of intronexon boundaries of all these genes revealed only non pathogenic sequence variants. However, the presence of intragenic deletions or of regulatory mutations in one of these genes cannot be ruled out at this moment.

Restriction of the critical ARVD1 region is essential for the progress of the investigation aiming at the identification of the involved gene. Hopefully, two research initiatives on ARVD, recently launched by European Community and by US National Health Institute, should succeed in reaching this goal soon.

\section{Acknowledgements}

The authors are grateful to all family members who kindly participated in this study and to Mrs Paola Marcon for her invaluable help in collecting family data. The project upon which this publication is based was performed pursuant to Baylor College of
Medicine Grant No. 1 U01 HL 65652 from the National Institutes of Health and to Department of Biology, TELETHON Grant No. 1288, MURST Grant No.2001063199 and ARVC EC contract No. QLGd-CT-2000-01091. A Rampazzo and B Bruce are recipients of a research assistant temporary position, pursuent to ARVC EC control QLG1-CT-2000-01091.

\section{References}

1 Basso C, Thiene G, Corrado D, Angelini A, Nava A, Valente M: Arrhythmogenic right ventricular cardiomyopathy. Dysplasia, dystrophy, or myocarditis? Circulation 1996; 94: 983-991.

2 Nava A, Bauce B, Basso C et al: Clinical profile and long-term follow-up of 37 families with arrhythmogenic right ventricular cardiomyopathy. J Am Coll Cardiol 2000; 36: 2226-2233.

3 Corrado D, Thiene G, Nava A, Rossi L, Pennelli N: Sudden death in young competitive athletes clinicopathologic correlations in 22 cases. Am J Med 1990; 89: 588-596.

4 Rampazzo A, Nava A, Danieli GA et al: The gene for arrhythmogenic right ventricular cardiomyopathy maps to chromosome 14q23-q24. Hum Mol Genet 1994; 3: 959-962.

5 Rampazzo A, Nava A, Erne P et al: A new locus for arrhythmogenic right ventricular cardiomyopathy (ARVD2) maps to chromosome 1q42-q43. Hum Mol Genet 1995; 4: 2151-2154.

6 Severini GM, Krajinovic M, Pinamonti B et al: A new locus for arrhythmogenic right ventricular dysplasia on the long arm of chromosome 14. Genomics 1996; 31: 193-200.

7 Rampazzo A, Nava A, Miorin M et al: ARVD4, a new locus for arrhythmogenic right ventricular cardiomyopathy, maps to chromosome 2 long arm. Genomics 1997; 45: 259-263.

8 Ahmad F, Li D, Karibe A et al: Localization of a gene responsible for arrhythmogenic right ventricular dysplasia to chromosome 3p23. Circulation 1998; 98: 2791-2795.

$9 \mathrm{Li}$ D, Ahmad F, Gardner MJ et al: The locus of a novel gene responsible for arrhythmogenic right-ventricular dysplasia characterized by early onset and high penetrance maps to chromosome 10p12p14. Am J Hum Genet 2000; 66: 148-156.

10 Melberg A, Oldfors A, Blomstrom-Lundqvist C et al: Autosomal dominant myofibrillar myopathy with arrhythmogenic right ventricular cardiomyopathy linked to chromosome 10q. Ann Neurol 1999; 4: 684-692.

11 Tiso N, Stephan DA, Nava A et al: Identification of mutations in the cardiac ryanodine receptor gene in families affected with arrhythmogenic right ventricular cardiomyopathy type 2 (ARVD2). Hum Mol Genet 2001; 10: 189-194.

12 Rampazzo A, Pivotto F, Occhi G et al: Characterization of C14orf4, a novel intronless human gene containing a polyglutamine repeat, mapped to the ARVD1 critical region. Biochem Biophys Res Commun 2000; 278: 766-774.

13 Ahmad F, Gonzalez O, Ramaldi L et al: Identification and characterization of a novel gene (C4orf5) located on human chromosome $4 \mathrm{q}$ with specific expression in cardiac and skeletal muscle. Genomics 2000; 70: 347-353. 
14 Li D, Gonzalez O, Bachinski LL, Roberts R: Human protein tyrosine phosphatase-like gene: expression profile, genomic structure, and mutation analysis in families with ARVD. Gene 2000; 256: $237-243$.

15 Li D, Bachinski LL, Roberts R: Genomic organization and isoformspecific tissue expression of human napor (cugbp2) as a candidate gene for familial arrhythmogenic right ventricular dysplasia. Genomics 2001; 74: 396-401.

16 McKenna WJ, Thiene G, Nava A et al: Diagnosis of arrhythmogenic right ventricular dysplasia/cardiomyopathy. Task Force of the Working Group Myocardial and Pericardial Disease of the European Society of Cardiology and of the Scientific Council on Cardiomyopathies of the International Society and Federation of Cardiology. Br Heart J 1994; 71: 215-218.

17 Altschul SF, Madden TL, Schaffer AA et al: Gapped BLAST and PSIBLAST: a new generation of protein database search programs. Nucleic Acids Res 1997; 25: 3389-3402.

18 Valente M, Calabrese F, Thiene G et al: In vivo evidence of apoptosis in arrhythmogenic right ventricular cardiomyopathy. Am J Pathol 1998; 152: 479-484.

19 Ponting CP: Novel repeats in ryanodine and IP3 receptors and protein O-mannosyltransferases. Trends Biochem Sci 2000; 25: $48-50$.

20 Ervasti JM, Campell KP: Membrane organization of the dystrophin-glycoprotein complex. Cell 1991; $66: 1121-1131$.
21 Suzuki A, Yoshida M, Hayashi K, Mizuno Y, Hagiwara Y, Ozawa E: Molecular organization at the glycoprotein-complex-binding site of dystrophin. Three dystrophin-associated proteins bind directly to the carboxy-terminal portion of dystrophin. Eur J Biochem 1994; 220: 283-292.

22 Ervasti JM, Campell KP: A role for the dystrophin-glycoprotein complex as a transmembrane linker between laminin and actin. J Cell Biol 1993; 122: 809-823.

23 Barnard JA, Lyons RM, Moses HL: The cell biology of transforming growth factor beta. Biochim Biophys Acta 1990; 1032: 79-87.

24 Brown TL, Patil S, Cianci CD, Morrow JS, Howe PH: Transforming growth factor-beta induces caspase 3-independent cleavage of alphaII-spectrin (alpha-fodrin) coincident with apoptosis. J Biol Chem 1999; 274: 23256-23262.

25 Ruoslahti E, Pierschbacher MD: Arg-Gly-Asp: a versatile cell recognition signal. Cell 1986; 44: 517-518.

26 D'Souza SE, Ginsberg MH, Plow EF: Arginyl-glycyl-aspartic acid (RGD): a cell adhesion motif. Trends Biochem Sci 1991; 16: 246250.

27 Bauce B, Nava A, Rampazzo A et al: Familial effort polymorphic ventricular arrhythmias in arrhythmogenic right ventricular cardiomyopathy map to chromosome 1q42-43. Am J Cardiol 2000; 85: 573-579. 